\title{
Surveillance, Risk and Preemption on the Australian Border
}

\section{Dean Wilson ${ }^{1}$ and Leanne Weber ${ }^{2}$}

\begin{abstract}
In this paper we will map and analyze Australian border surveillance technologies. In doing so, we wish to interrogate the extent to which these surveillance practices are constitutive of new regimes of regulation and control. Surveillance technologies, we argue, are integral to strategies of risk profiling, social sorting and "punitive pre-emption.” The Australian nation-state thus mirrors broader global patterns in the government of mobility, whereby mobile bodies are increasingly sorted into kinetic elites and kinetic underclasses. Surveillance technologies and practices positioned within a frame of security and control diminish the spaces that human rights and social justice might occupy. It is therefore imperative that critical scholars examine the moral implications of risk and identify ways in which spaces for such significant concerns might be forged.
\end{abstract}

\section{Introduction}

Since the attacks of September 11 Australian authorities have increasingly redefined mobility as a problem of security. Such a redefinition has endeavored to position mobility "above the realm of normal politics" where considerations of social justice are evaded and questions of "effectiveness" emerge as paramount (Loader 2002: 137). This securitization agenda is operationally apparent through the amplification of surveillance practices on and beyond the border. ${ }^{3}$ Aas (2005) has argued that in a world characterized by global flows, zones and networks, it is technology, rather than geography, that increasingly defines the space of governance. The policing of global mobility now takes place in "informated space" through transnational networks aimed at the "bureaucratic production of knowledge about suspect populations" (Sheptycki 1998: 70). Advance passenger processing, the compilation of databases of "high risk" travelers, the biometric identification of asylum seekers and biometric passports are all developments that

\footnotetext{
1 School of Political and Social Inquiry, Monash University. mailto:Dean.Wilson@arts.monash.edu.au

2 School of Social Sciences and International Studies, University of New South Wales. mailto:l.weber@unsw.edu.au

${ }^{3}$ For more detailed discussion of the concept of securitization see Ole Wæver (1995) 'Securitization and Desecuritization’ in R. Lipschutz (Ed) On Security. New York: Columbia University Press, 46-86; see also M. Williams (2003) 'Words, Images, Enemies: Securitization and International Politics', International Studies Quarterly, 47: 511-531.
} 
evidence and simultaneously reinforce the increasing securitization of mobility. Bigo has suggested that across the global north the "securitization of immigration is the result and not the cause of the development of technologies of control and surveillance" (2002: 73, emphasis added). This may overstate the constitutive role of technology in processes of securitization. Nevertheless, where leading-edge technologies operate beyond borders in "transnational interstices of state power" (Sheptycki 1995: 629), they frequently emerge in advance of legal legitimation and systems of constraint.

In this paper we will map and analyze Australian border surveillance technologies operating within the interstitial spaces of international air travel. In doing so, we wish to interrogate the extent to which these surveillance practices are constitutive of new regimes of criminalization and control. We argue that the anticipatory regimes of border control which govern these spaces, while primarily risk reducing in their mentality, may be punitive in their effect. Following Johnston and Shearing (2003) we characterize these hybrid governmentalities as regimes of "punitive preemption.” Punitive preemption may incorporate a range of disciplinary, punitive and militaristic technologies aimed at preempting arrival at the physical border (Weber forthcoming). While military surveillance strategies have been a prominent feature of interdiction measures intended to preempt arrival in Australia by sea, a detailed analysis of these practices is beyond the scope of this article. Here we wish to interrogate the extent to which bureaucratic forms of surveillance connected with international air travel are constitutive of these new anticipatory regimes of regulation and control.

We argue that surveillance technologies are integral to strategies of punitive preemption based on "social sorting" - the filtering of individuals in relation to coded categories of high or low risk (Lyon 2003). The Australian nation-state thus mirrors broader global patterns in the government of mobility, whereby mobile bodies are increasingly sorted into kinetic elites and kinetic underclasses (Adey 2006). Bauman has described the same process in terms of the ideal types of "global tourists" and "global vagabonds" (1993: 240-243). The deployment of surveillance technologies and practices in the Australian context serves in the production of the two tiers of mobility he identifies as "the extraterritoriality of the new global elite and the forced territoriality of the rest" (Bauman 2000: 221). These practices of selective immobilization have human rights implications in relation to asylum seekers, and raise broader questions of social justice in a world increasingly divided into the "mobility rich" and "mobility poor" (Pickering and Weber 2006; Wilson 2006; Wonders 2006).

\section{Sec unitization and Preemption of Informated Space}

The heightened regulation and surveillance of borders occurs within a political context in which social problems are increasingly reconfigured as problems of security. Prior to the events of September 11, Simon (1997) noted the increased tendency in the US to "govern through crime," whereby criminal justice solutions were widely advanced for social problems. Loader (2002) has identified parallel trends in the "securitization of Europe," including the identification of unregulated border crossing as a security concern. Australia has witnessed similar developments, and this can be attributed to changes in governance 
during the 1980s, whereby neo-liberal states moved away from the provision of services to promoting and promising safety - a promise intertwined with the rise of "law and order” politics (McCulloch 2004a). Post September 11 there has been an amplification of this trend as social and economic problems are progressively reconfigured and interpreted through the prism of security (McCulloch 2004b). This securitization is manifested externally as well as internally. Thus in Australia, as elsewhere in the global north, cross border mobility is increasingly viewed as an external and internal security threat. In fact, in the context of the challenges to state sovereignty presented by globalization, it could be argued that irregular border crossing has attained a preeminent status as a political symbol of national insecurity, and therefore as a focus for governmental control. Faced with the contradictions and insecurities arising from "globalization," developed states have sought to reinforce their territorial borders when, on many other levels, the salience of borders has been in decline (Weber and Pickering 2006). Sassen has identified border crossing as a "strategic site of inquiry about the limits of the new order" (1996: xvi).

A consequence of governing mobility through the prism of security has been the progressive criminalization of spontaneous border crossing by asylum seekers and others. Criminalization has been evident at the level of political discourse (Pickering 2001) and in punitive practices such as fingerprinting and administrative detention of targeted groups (Pickering 2005; Weber 2002; Welch and Schuster 2005). However, mirroring trends in crime control (Garland 1996), criminalization and deterrence regimes have increasingly been supplemented with more pragmatic measures aimed at reducing and managing risk in the face of persistently high levels of border crossing. Feeley and Simon (1994) predicted that the development of risk management policies would be a likely response to the diminishing ability to control global mobility through conventional means. Aradau and Van Munster argue that risks such as terrorism, which are judged to be both unmanageable through the normal prudential techniques of social sorting, and irreversible in their effects, mobilize a range of precautionary technologies including war, generalized surveillance, and decisive administrative action based not on specific knowledge but on attributions of dangerousness. They note that these technologies span the whole space between two definitions of securitization, which is between "exceptional measures and the immediacy of action on the one hand" and the "ordinary administrative, police or insurance measures on the other" (2007: 98). This recognition of both exceptional (punitive) and routine (administrative) applications of precautionary principles appears to be congruent with the hybrid mentalities of punitive preemption discussed earlier in relation to border control. The equating of uncontrolled border crossing with loss of sovereignty, and its conflation with the terror threat, has elevated border anxiety to the status of a catastrophic risk against which governments have been prepared both to take urgent action (such as the landing of armed troops on the MV Tampa and the assembling of the Pacific Solution ${ }^{4}$ ) while also investing in more routine preemption regimes.

The growth of administrative risk reducing strategies has been attended by a substantial expansion of database processing capacity and surveillance infrastructure intended to

\footnotetext{
4 The absolute refusal of the Australian government to allow the landing on Australian soil of a Norwegian merchant vessel which had rescued stricken asylum seekers en route from Indonesia sparked a preemptive regime of naval interdiction and offshore detention which have been widely discussed elsewhere (see Carrington 2006; Taylor 2005a; Weber 2006; Weber forthcoming).
} 
strengthen border control processes. This information capacity is linked inextricably to the yearning for "risk knowledge" observed by Ericson and Haggerty (1997) in relation to police surveillance. As Lyon notes, risk knowledge is increasingly synonymous with information technologies and databases (2006a: 73). Information technology has also been pivotal in the externalization of the border. Aas has observed that new technologies "seem both to transform the traditional space of government and to disrupt territorial boundaries," as well as appearing to provide the most efficient solution to problems of risk and security (2005: 207). The borders of the global north are fast becoming high-tech borders, "capable of materializing in different sites around the globe" (Walters 2006: 197). Actuarial logic requires that containment measures be applied before any harm results (Rose 2000, Shearing and Johnston 2005). Risk thinking in relation to border control therefore leads inexorably to temporal, and hence spatial, displacement of the border. Weber has discussed elsewhere the dispersal of the border to multiple "sites of enforcement," both internal and external to the physical border of the state (Weber and Bowling 2004). The delocalised, technologically realized border is "performed" by state agents on traveling bodies rather than drawn as a line on a map (Wonders 2006); is functional rather than physical (Weber 2006), and significantly reorganizes the spatiality of power (Walters 2006).

The logic of exclusion inherent in border control, coupled with mentalities of "risk reduction" and corresponding information technologies, produces strategies of "preemptive immobilization" aimed at certain categories of traveler who conform to set criteria. These risk profiles are constructed using aggregate information about suspect populations, and applied through information technologies accessed by immigration authorities and their agents on or before the border. Surveillance technologies therefore expand the potential codes and categories of risk (O’Malley 2006). Increasingly, these aggregate techniques of exclusion bear little relationship to any "objective" measure of individual risk. Numerous commentators have noted a widespread blurring of the distinction between individual suspicion and guilt in the name of collective security (e.g. Coleman and Sim 2005; Zedner forthcoming; McCulloch and Carlton 2006). With respect to Australian border controls, Taylor has noted that, while every asylum seeker who has managed to evade preemptive measures to reach Australian shores by sea has been subjected to mandatory detention and security screening, none had been assessed as posing an actual individual security risk (Taylor 2005a). ${ }^{5}$ Individual checking may be applied within these categories, both at and before the border, using persons of interest databases (such as the MAL system discussed later) or other discretionary methods. However, these operational practices are not discernible in official documentation and are largely beyond the scope of this discussion. ${ }^{6}$ The generalized image of threat and danger associated with illegalized border crossing has been hotly contested by critical

\footnotetext{
5 This applied up to 30 June 2003. Since then, a single offshore detainee was refused entry to Australia on security grounds but later accepted as a refugee elsewhere, raising doubts about the security assessment.

6 The focus of this discussion is the early screening out of travelers at visa issuing and transit stages of travel, through the use of aggregate level sorting mechanisms, not on the more humanly mediated mechanisms which may apply on arrival at the physical border (for which see Parsley 2003). It is important to note that recent Australian immigration policy has been remarkable for its attempt to shrink the spaces available for individual discretion and has been criticized on these grounds by the UN Human Rights Committee, for example, in relation to the use of detention ( $A v$ Australia (1997) Communication No. 560/1993, CCPR/C/59/D/560/1993, 30/4/1997).
} 
commentators, particularly in the case of asylum seekers who should benefit from the universal right to seek sanctuary from persecution (see for example Green and Grewcock 2002, Pickering 2001, Welch and Schuster 2005). However, paradigms of risk are largely blind to considerations of individual circumstance and, particularly when operating within the "transnational interstices of state power," may become detached from the normal constraints of territorially-based legal regulation (Sheptycki 1995: 629).

\section{The Australian Border: Politic s and Policy}

Although indicative of patterns of border securitization across the global north, the surveillance and policing of the Australian border has a specific genealogy. While the number of displaced persons crossing Australia's borders is numerically far less than in the EU or US, the specific history of Australia as a colonial settlement infuses the border with potent political symbolism (Carrington 2006: 198). As a British colony situated in the Asia Pacific region Australia has a history of invasion anxiety fired by xenophobic narratives which envisage the white Australian nation being overrun by Asiatic multitudes descending from the north (Burke 2001). These racialized narratives have informed and intensified the contemporary politicization and securitization of border control in Australian public debate. The merging of border anxiety and security was nowhere clearer that in Australia's federal election campaign of 2001. On 26 August 2001 a Norwegian vessel, the MV Tampa, arrived off the Australian coast carrying 430 asylum seekers, primarily of Afghani and Iraqi origin, who had been rescued from a leaky boat attempting the journey from Indonesia to Australia. The incident supplied Prime Minister John Howard with an emotive issue that unleashed entrenched fears within the Australian electorate about invasion, outsiders and the defense of national sovereignty (McCulloch 2004a; Marr \& Wilkinson 2003). The attack of September 11 only two weeks after the arrival of the Tampa in Australian waters propelled border security to the centre of the electoral debate and conflated the identities of asylum seekers with potential terrorist threats (McCulloch 2004a).

Since then, Australia has witnessed an acceleration of expenditure on human and technological security measures at and beyond the border. This has involved the development of an extensive searchable database capacity, the deployment of biometric technology, increased interoperability and data exchange between government agencies, increased cooperation and interoperability with other nation-states beyond the territorial border and the extensive deployment of human surveillance. Examples of expanding human surveillance capacities include overseas networks of federal police and immigration liaison officers tasked with monitoring and disrupting people smuggling activities, and enhanced coastal surveillance coupled with military interdiction at sea. These efforts have been supported by significant investments in information technology, the establishment of intelligence coordination centres both onshore and offshore, and the installation of secure satellite tracking systems on coastal surveillance vessels (ACS 2006c, DIMIA 2005; see also Pickering 2004; Taylor 2005b; Weber forthcoming; Weber 2006). ${ }^{7}$

7 Over the last decade the government department responsible for immigration has been known as the
Department of Immigration and Multicultural Affairs (DIMA), the Department of Indigenous, Immigration 
These developments are consistent with a growing "market in security" described by Garland (1997), amongst others, primarily in relation to technology. It has been observed that the government is one of the key consumers of security products in "the fear economy" (Davis 2001). The Australian government has also been an active exporter of border surveillance technologies, and of risk reducing border control policies more generally. Annual reports and ministerial press releases note that training for airline staff in detection of fraudulent documents has been provided by Australian officials in a wide range of countries, and that the expertise of Australian border control officials is in high demand, for example through "capacity-building" initiatives in countries such as Indonesia, Afghanistan and Papua New Guinea (DIMIA 2004). Moreover, this exemplifies the active creation of a market for Australian border control expertise: a demand for this knowledge is first generated via the imposition of carrier sanctions (discussed later), then filled through capacity building training.

The Australian government has also promoted the development of computerized Advanced Passenger Information (API) systems in countries of transit, through so-called "pathfinder" projects endorsed by the Asia-Pacific Economic Cooperation (APEC) group. By 2004, API Feasibility Studies had reportedly been conducted in South Korea, Chile and Tapei, with more studies planned, for example, in the People's Republic of China (DIMIA 2004). The same report cited capacity building exercises in over 20 Asia-Pacific and Middle Eastern countries covering border management assessments; system design and implementation; establishment of document examination laboratories, including the creation of an Identity Checking Unit in Afghanistan; assistance with legal drafting; provision of equipment and training in detection of document fraud, assistance with immigration intelligence, and English language training. Coupled with the placement of Australian immigration officials at key points of transit to Australia, the Australian government has therefore created a formidable offshore network which operates to sort, immobilize and preempt unwanted arrivals at the physical border.

\section{Surveillance and Pre-emption: APP, MALand RMAL}

Australia operates its offshore border through a computerized information network called Advance Passenger Processing (APP). Salter discusses the delocalization of the border function through visas (Salter 2006). Australia enforces a system of universal visa coverage, supported by highly developed information technologies and comprehensive surveillance. The system enables information exchange, passenger monitoring and administrative processing to commence from the time an intending passenger applies for a visa or attempts to board a flight for Australia. The preemptive mentality which underlies this approach is clear from this extract from an immigration department report: "Australia manages the movement of non-citizens across its border by, in effect, pushing the border offshore. This means that checking and screening starts well before a person reaches our physical border” (DIMIA 2004: 3). Electronic travel authorities (ETAs) are available to

and Multicultural Affairs (DIMIA) and the Department of Immigration and Citizenship (DIAC). For consistency the generic term immigration department will be used throughout, unless citing a particular publication or where used in a direct quotation. 
favored nationalities with low recorded risk profiles. These profiles are constructed from aggregate statistics on breaches of visa conditions (a putative illegal practice) and incountry applications for asylum (a completely legal practice), and are doubtlessly influenced by foreign policy concerns. The name of the document is revealing in itself. It is an electronic travel authority - effectively a mobility permit, not simply a permission to enter Australia. This shift of focus to points of embarkation and transit constitutes a preemptive performance of the Australian border at points far distant from its physical location, aimed at selective immobilization. Coupled with carriers' liability sanctions which force the cooperation of commercial airline officials in screening and sorting passengers on behalf of the Australian state, Australian immigration authorities are effectively regulating mobility through informated spaces over which they have no legitimate sovereign control (Taylor 2005b).

The process of social sorting inherent in Advance Passenger Processing is evident not only in the profiles applied within the system, but in the initial distinction between electronic and paper applications. Sorting therefore commences from the time of application to travel, long before presentation at an international port. Intending travelers from "suspect" nationalities are subjected to greater scrutiny by Australian visa processing officials and have their photograph kept on file. Those from nationalities whose "suspect status" with respect to non-compliance with border controls is routinely assumed, are likely to have their visa refused. This is particularly true of nationalities which account for a significant proportion of onshore asylum applications, even though unlawful arrival in order to lodge an asylum application is permissible under international refugee conventions. Taylor has observed that "[a]s a result of DIMIA's ever improving "risk management" techniques, potential asylum seekers are less and less likely to be granted visas for travel to Australia as evidenced by the downward trend in the proportion of visitor visa entrants making protection visa applications over the past few years" (Taylor 2005b). This points to the effectiveness of offshore screening in immobilizing "high risk travelers," a practice which potentially leads to refoulement of refugees (that is, forced return to danger) and other breaches of the right to seek asylum. It is notable that the APP system is also geared towards improving the efficiency of processing "low risk" passengers. These official practices are therefore instrumental in the formation of both kinetic elites and kinetic underclasses (Adey 2006).

The Advance Passenger Processing (APP) system is supported by an extensive network of Airline Liaison Officers (ALOs) who work closely with commercial airline employees to screen passengers during check-in and boarding. Since Australian immigration officials have no statutory powers in the interstitial spaces of international airports, it is an airline employee who technically makes the decision about whether to allow a passenger to board. However, these decisions are based on a directive generated by the APP system that it is "OK to Board" or "Not OK to Board," so that social sorting in compliance with Australian border control policies is generally achieved. Final checking of authorization to enter is conducted by Australian Customs officials at the physical border. However, long before a traveler arrives at the border, an EMR (expected movement record) will have been generated to ensure that "Australian border agencies are aware of the expected travel to Australia of all persons and can tailor their response accordingly" (DIMIA 2004: 4). 
Preemption of unauthorized arrival is also facilitated by the Movement Alert List (MAL). The MAL system is a computer database storing details of individuals and travel documents that are believed to be of "immigration concern." MAL alerts may be based purely on previous immigration history, or may relate to intelligence information fed into the system by security services, visa issuing authorities abroad, or the Australian Federal Police (AFP). The AFP's Promise system and the PACE and PAES (Passenger Analysis and Evaluation System) databases managed by the Australian Customs Service, are linked in various combinations by a series of Memoranda of Understanding (David 2000). This extensive network of data sharing extends the scope of surveillance beyond the APP system, to incorporate assessments of risk at a more individualized level. While it is not clear whether MAL alerts are available routinely during all stages of offshore passenger processing, it seems they are accessed by officials charged with issuing visas abroad through the Travel and Immigration Processing System (TRIPS). The MAL system is promoted by immigration authorities as a "key tool" in applying legislation governing the entry to and presence in Australia of "non-citizens who are of character concern" (DIMA 2006). While MAL may not raise the objections associated with the aggregate level profiling characteristic of the APP system, questions of data integrity and due process are likely to arise, and the sheer scope and inherent lack of transparency of the system gives cause for concern. In June 2006 there were approximately 450,000 identities listed on MAL and a further 2.29 million documents of concern (DIMA 2006). In 2005 the Government allocated AU\$43.9 million to the development of the MAL, including redeveloping the alert system, creating a dedicated 24 hour centre and improving links with other Government agencies, particularly the Australian Security Intelligence Organization (ASIO). Collectively, these surveillance systems provide generalized monitoring of both actual, and intended, crossings of the Australian border.

The border is further delocalized through surveillance practices and information exchange involving cooperation with other nation-states, particularly within the Asia Pacific region, as outlined in the previous section. In key South East Asian locations, the Australian Government is also providing intelligence training for local border patrols and funding the installation of Closed Circuit Television (CCTV). Significant funds (AU\$6.4 million) have been allocated towards assisting Indonesia to enhance its border movement alert system (Australian Government 2006: 21). Furthermore, the Australian Government is providing \$AU10.9 million towards the development of RMAL (Regional Movement Alert List). RMAL is an APEC initiative, a connection which reveals the economic factors at play in efforts to control cross border movements. After an initial tri-lateral pilot involving the US, Australian and New Zealand, the RMAL is intended to become a fully operational, regional system. Designed to detect lost, stolen and invalid travel documents the system allows real time access to the databases of cooperating nation-states. Work is currently underway to expand the database from lost and stolen passports to all passports; a move that it claims would "enable authorities to check the validity and authenticity of other economy's travel documents” (APEC 2007). This reflects an enormous investment in exclusionary technologies and transnational networks designed, ostensibly, to protect national economies, but at a cost to governments which points also to the significant political capital accrued through the securitization of borders. 


\section{Biometrics, Asylum Seekers \& Criminalization}

We have argued so far that the capacity to secure borders has been a crucial arena in which the Australian state has sought to reconfigure mobility as a problem of security. An integral aspect of this security politics has been the discursive criminalization of those seeking asylum in Australia. This process of criminalization is clearly evident in media reporting, which has depicted asylum seekers as deviant, diseased and threatening to infect the nation and undermine national sovereignty (Pickering 2001). Public narratives in Australia have also constructed refugee identities as "illegal" "fraudulent" and "bogus." The security continuum identified by Huysmans linking border control, terrorism, international crime and migration in the European Union has also emerged strongly in the Australian context (2000: Pickering 2005). The authority to inscribe legitimate and illegitimate identities on those moving across borders is therefore positioned within a broader discourse of border security and sovereignty.

It is against this politicized backdrop that the Australian Parliament passed the Migration Legislation Amendment (Identification and Authentication) Act 2004. The legislation amended the Migration Act 1958, increasing the basis for taking biometric identifiers such as photographs, signatures and fingerprints. The proclaimed rationale of the legislation is to increase the ability of border authorities to "establish and authenticate the identity of non-citizens at various stages of immigration processing, and on entry to and departure from Australia (DIMIA 2004). The programme is being generously funded by the Australian Commonwealth Government, with \$A42.87 million allocated to implement "biometric technology for border security and identity management" (Bajkowski 2005). Practices such as fingerprinting, can amount to "quasi" or "indirect" criminalization, particularly when these requirements are selectively targeted (Weber 2002). Appearing before the Australian Senate's Legal and Constitutional Legislation Committee, John Gibson of the Victorian Bar claimed that the "invasive and demeaning processes" inherent in the legislation would "only increase the sense that, in some circumstances, particular individuals seeking asylum in Australia are treated worse than criminals" (Commonwealth of Australia Senate Legal and Constitutional Legislation Committee 2003: 5-6).

The use of the technology is intertwined in a wider process of criminalization. Facial recognition technology, iris scanning and fingerprinting are part of an overall strategy of identity management intended to "strengthen identification processes" (DIMIA 2004). Asylum seekers are criminalized in the enactment of this initiative through the discursive fusing of mobility and criminality, and through their subjection to criminal-justice-like procedures. Immigration Department publicity for the measure notes that assembling a biometric database of asylum seeker details will: “improve Australia's border security. It will help to fight against the use of sophisticated techniques exploited by terrorists and criminals, to change identities and cross international borders" (DIMIA 2004). Importantly, technology is promoted as the crucial barrier to fortify permeable borders. As the explanatory memorandum to the legislation notes: "it is crucial that Australia has the opportunity and ability to participate internationally in combating immigration fraud by using current and evolving technologies. In this international environment, Australia cannot afford to be seen as a "soft target" by terrorists, people smugglers, forum shoppers 
and other non-citizens of concern" (Parliament of the Commonwealth of Australia 2003: 6). Everyone from global terrorists and alleged international criminals, to those seeking a receptive location to lodge a claim for refugee protection and forced into illicit modes of travel, or people merely attempting to travel without a valid visa, is thereby subsumed under the immigration fraud label, justifying a further widening and deepening of the surveillance apparatus.

Biometric technologies deployed upon the bodies of asylum seekers serve to intensify the securitization of border crossing and the criminalization of persons seeking refuge in Australia. The association of illegalized border crossers with biometric technologies fuses a disparate array of amorphous dangers - terrorism, organized crime and uncontrolled migration - as a single unified threat to national sovereignty. But such documents are also crucial signifiers of exclusion. In practice they inscribe on those seeking asylum the identity of "non-citizen." Fixing these "non-citizen" identities through biometric documentation magnifies categories of exclusion and reinforces the notion of border crossing as a problem of security. Moreover, subjecting asylum seekers to technological processes of classification possibly removes them from the discretion that can attend interaction with human agents. In the process, human judgements of justice, fairness and legitimacy are potentially superseded by automated processes (Lyon 2004: 2).

\section{Aiports, Kinetic Elites and the Ubiquitous Border}

Australian airports have also become pivotal sites where the securitization of mobility is enacted. A recent report on Australian airport security noted that airports "embody the modern world in all its complexity, since few other places bring together our most advanced technological creations and the intricate interconnected systems we have devised to serve both those creations and ourselves" (Wheeler 2005: 5). The September 11 attacks were instrumental in the development of heightened security measures in airports across Western nations, and in fixing airports in public consciousness as filters of risk (Adey 2004; Lyon 2006b). Airports have subsequently assumed considerable symbolic capacity as nodes of risk management and border control (Salter 2007). This significance is linked to the crucial role of airports as risk filters where processes of social sorting are enacted (Lyon 2006b: 405). Unsurprisingly then, the Australian Government has expended considerable resources on fortifying the nation's airports against potential security threats. In 2005 an extensive review of Australian airport security was undertaken by Sir John Wheeler, who had conducted a similar review in the UK. Following Wheeler's report, \$A200 million was budgeted to facilitate reinforced airport security, with measures including enhanced explosive detection technology, augmented closed circuit television surveillance, security training and specialized Airport Investigation Teams (Howard 2005).

Biometric identification systems are integral risk filters in these emergent regimes of intensified security. Examples include the SmartGate Series 1 facial recognition system, which is due to commence full scale operation at Sydney, Melbourne and Brisbane airports in 2007, with other international Australian airports to follow (Australian Customs Service 2006a). The SmartGate system allows passengers with "ePassports” to 
check themselves through Passport Control via a kiosk which takes an image of the traveler's face and matches that against the holder's passport image. Between November 2002 and June 2005 trials were undertaken at Sydney and Melbourne airports, initially involving crew of the national carrier Qantas, later followed by selected "frequent flyers." The actual efficacy of the SmartGate system is disputed (Clarke 2004; ABC Online 2006). Nevertheless, SmartGate Series 1 is to be introduced in 2007. The system encapsulates the development noted by those examining contemporary trends in airport surveillance where individuals are sorted into slow-moving and fast-moving streams (Adey 2006; Lyon 2006b). One of the proclaimed benefits of SmartGate is that it will enable Customs Officers to focus on "high-risk" travelers and "enhance the security of the Australian border" while simultaneously facilitating the rapid processing of "low-risk" travelers (Australian Customs Service 2006a).

The capacity to sort between "low risk" and "high risk," between desirable and undesirable, is intensified through the biometrification of the international passport system. Passports are the primary document for identifying, regulating and tracing mobile individuals. The passport is, as Salter suggests, "a modern heuristic device which serves to link individuals to foreign policy, and according to which government agents classify travelers as safe or dangerous, desirable or undesirable, according to national, social or political narratives" (Salter 2004: 72). The most frequent rationale given for incorporating biometric data into travel documents is "national security" - meaning security from "illegal" migrants and those labeled terrorists (Thomas 2005: 16). In Australia the potential for passports to facilitate processes of risk profiling and "social sorting" are advanced through the implementation of the ePassport, a biometric document using facial recognition technology introduced by the Australian Department of Foreign Affairs and Trade (DFAT) in October 2005 (Australian Customs Service 2006b). The ePassport has a microchip embedded in the centre page containing a digitized facial image and the personal details of the holder (Downer 2005). Australia is issuing biometric passports in response to the standards set by the International Civil Aviation Organization (ICAO). Australia's Foreign Minister has claimed biometric passports will "speed up movements through airport controls, boost aviation security and curtail identity theft. It should also prove invaluable in the fight against terrorism, people smuggling and other transnational crimes” (Downer 2003). However, as Privacy International has suggested, biometric passport systems, often justified as a means of combating terrorism, will facilitate the compilation of significant national biometric databases while bypassing meaningful public debate (2004). This was evident in the passage of the Australian Passports Bill 2004 which passed through both Houses of the Australian Parliament with support from both major political parties.

The Australian Passports Act 2005 has significant implications in terms of data, surveillance and citizenship. The broad language of the legislation opens the possibility of a database of biometric information for every holder of an Australian passport or travel document (Donaldson 2004: 6). A database so assembled could soon begin to function as "a de facto national biometric database for use by the Government in a broad range of circumstances” (Donaldson 2004: 7). Biometric passports amplify the surveillance and database capacity of government. As the International Campaign Against Mass Surveillance succinctly suggested, biometric passports represent the potential of obtaining "nearly universal registration of everyone on the planet" (2005: 8). Processes of 
securitization are thus coupled and intertwined with significant extensions of data collection and the capacity to process it. The increased interconnection between databases and the sharing of information between agencies, and the enhanced classificatory capacity this unleashes - as "high risk" rather than "low risk," or suspected rather than trusted potentially deepens and widens the discriminatory and exclusionary processes of border policing (Amoore 2006; Wilson 2006; Muller 2004). As van der Ploeg suggests, surveillance practices at the border "produce infinitely better inhabitable identities for some people than others” (2006: 193).

Searchable databases generated by biometric passport registration facilitate intensive processes of "social sorting" where processes of exclusion and inclusion are deepened and extended. In their influential article, Feeley and Simon (1994) suggested that one of the characteristics of actuarial justice was the movement of exceptional powers - usually reserved for border areas such as airports and border posts - to the internal spaces of the nation-state. Such an observation could also be made of surveillance practices and technologies, where the compiling of digital databases and the securitization of mobility increasingly extends internally as well as externally.

\section{Conclusion}

Australian border control is an example of securitization whereby the regulation of mobility is separated from human rights and social justice frameworks and configured as a problem of security and enforcement. Thus, asylum seekers and other spontaneous border crossers are increasingly presented "not as people who have a problem but as people who are a problem" (Joly 1997: 35) and the regulation of border crossing is positioned within a political and policy process geared towards crime and control. As Bauman suggests, this is a process that moves towards a "logic of exclusion and fortification” (2000: 205). Surveillance practices and technologies are integral components within this process of exclusion and fortification. In the Australian context Advance Passenger Processing, the Movement Alert List, the Regional Movement Alert List, the biometric identification of asylum seekers and the introduction of the ePassport are constitutive and symbolic components of the securitization of mobility. These searchable databases and biometric identification systems engaged in the mission of social sorting at the border are not impartial. As Graham and Wood note of digital surveillance systems, while they may be characterized by flexibility and ambivalence, and contingent upon judgments of social and economic worth built into their design, they are "likely to be strongly biased by the political, economic and social conditions that shape the principles embedded in their design and implementation” (2003: 229).

The expansion of the technological capacity of databases, combined with human policing, has resulted in the intensive escalation of surveillance and preemptive practices at and beyond the Australian border. We have already noted that Australian border control measures are heavily freighted with political symbolism. However such measures also have important practical consequences, which follow from the processes of social sorting as outlined by Lyon (2003). In the case of asylum seekers and other border crossers, the normative prescriptions of international human rights law are especially fragile, and are 
easily set aside in the transnational, informated spaces in which preemptive border control occurs. Technocratic sorting practices at international airports use aggregate risk profiles to actively and routinely differentiate authorized and suspect travellers for differential treatment, primarily on the basis of nationality and ethnicity, thereby creating new channels of inequality (Wonders 2006). The material consequences of systemic failures to identify individuals in need of protection at the Australian border, and their possible return to places of danger, are potential breaches of Australia's human rights obligations (Taylor 2005b).

Surveillance technologies are thus deployed within a social context and organizing logic that inevitably heads towards exclusionary rather than inclusive functioning. This amplifies the potential for "actuarial justice" rather than social justice, where the objective is risk management and where predictors of dangerousness are engaged to pre-emptively target "problem" populations (Feeley \& Simon 1994). That such informated spaces are being compiled within a "state of exception," where decisions are increasingly based upon political will rather than the constraints of normative law, is further cause for concern (Agamben 2005). Surveillance technologies and practices positioned within a frame of security and control diminish the spaces that human rights and social justice might occupy. It is therefore imperative that scholars interrogate the ways in which spaces for such significant concerns might be forged.

\section{References}

Aas, K. (2005) “'Getting Ahead of the Game”: Border Technologies and the Changing Space of Governance,' In E. Zureik and M.B. Salter (eds) Global Surveillance and Policing: Borders, Security, Identity, Collumpton, Devon: Willan Publishing, 194-214.

ABC (Australian Broadcasting Corporation) Online (May 5, 2006) 'PM-Biometric "Smartgate” system to be introduced to Australian airports,' Accessed October 2, 2006, www.abc.net.au/pm/content/2006/s1632049.htm

Adey, P. (2004) 'Secured and Sorted Mobilities: Examples from the Airport,' Surveillance and Society, 1(4): 500-19.

Adey, P. (2006) “'Divided We Move”: The Dromologics of Airport Security and Surveillance,' In T. Monahan (ed.) Surveillance and Society: Technological Politics and Everyday Life, New York: Routledge, 195-208.

Agamben, G. (2005) State of Exception. Trans. K. Attell. Chicago: University of Chicago Press.

Amoore, L. (2006) 'Biometric borders: Governing mobilities in the war on terror,' Political Geography, 25: 336-51.

Aradau, C. and R. Van Munster (2007) 'Governing Terrorism Through Risk: Taking Precautions, (un)Knowing the Future,’ European Journal of International Relations, 13(1): 89-115.

Asia Pacific Economic Cooperation (APEC) (2007) Fact Sheet: Regional Movement Alert System (RMAS), $\quad$ Accessed 4 February 2007, www.apec.org/news_media/fact_sheets/regional_movement.Page.Print.html.

Australian Customs Service (2006a) SmartGate Series 1. SmartGate Fact Sheet \#04, Canberra: Australian 
Customs Service, Retrieved October 12, 2006, from www.customs.gov.au.

Australian Customs Service (2006b) ePassports. SmartGate Fact Sheet \#05, Canberra: Australian Customs Service, Accessed October 12, 2006, from www.customs.gov.au.

Australian Customs Service (2006c) Australian Customs Service Annual Report 2005-06, Canberra, Australian Customs Service.

Australian Government (2006) Budget 2006-07, Budget Paper No. 2 National Security-Preventing Terrorism. Canberra: Australian Government. Accessed December 2, 2006 www.budget.gov.au/2006-07/bp2/html/bp2 expense-02.htm.

Bajkowski, J. (2005, May 11) 'Budget 2005 - winners and losers,' Computerworld (no pagination). Accessed October 8 2006. from www.computerworld.com.au/index.php?id=918866272\&eid=255.

Bauman, Z. (1993) Postmodern Ethics. Oxford: Blackwell.

Bauman, Z. (2000) 'Social Issues of Law and Order,' British Journal of Criminology, 40(2): 205-21.

Bigo, D. (2002) 'Security and Immigration: Toward a Critique of the Governmentality of Unease,' Alternatives, 27: 63-92.

Burke, A. (2001) In Fear of Security: Australia's Invasion Anxiety. Sydney: Pluto Press.

Carrington, K. (2006) 'Law and Order on the Border in the Neo-Colonial Antipodes,' In S. Pickering and L. Weber (eds.) Borders, Mobility and Technologies of Control, Dordrecht: Springer, 179-206.

Clarke, R. (2004) Australian Government Tries to Make Facial-Recognition Look Good. Accessed October 15, 2006 www.anu.edu.au/people/Roger.Clarke/DV/SmartGate040207.html.

Coleman, R. and J. Sim (2005) 'Contemporary statecraft and the "punitive obsession”: a critique of the new penology,' In J. Pratt, D. Brown, M. Brown, S. Hallsworth and W. Morrison (eds.) The New Punitiveness: Trends, theories, perspectives, Cullompton: Willan, 101-18.

Commonwealth of Australia, Senate Legal and Constitutional Legislation Committee (2003) Migration Legislation Amendment (Identification and Authentication) Bill 2003. Official Committee Hansard, 8 September. Commonwealth of Australia: Canberra.

David, F. (2000) Human Smuggling and Trafficking: An overview of the response at the federal level, AIC Research and Policy Series. Canberra, Australian Institute of Criminology.

Davis, M. (2001) ‘The Flames of New York,’ New Left Review, 12: 34-50.

Department of Immigration and Multicultural Affairs (DIMA) (2006) Movement Alert List Fact Sheet 77. Accessed March 12, 2006 http://www.immi.gov.au/media/fact-sheets/77mal.htm.

Department of Immigration, Indigenous and Multicultural Affairs (DIMIA) (2005) Managing the Border: Immigration Compliance 2004-05 edition, Canberra, Department of Immigration, Indigenous and Multicultural Affairs.

Department of Immigration, Indigenous and Multicultural Affairs (DIMIA) (2004) Managing the Border: Immigration Compliance, Canberra, Department of Immigration, Indigenous and Multicultural Affairs.

Department of Immigration, Indigenous and Multicultural Affairs (DIMIA) (2004) 2003-04 Annual Report, Canberra, Department of Immigration, Indigenous and Multicultural Affairs. 
Donaldson, M. (2004) Australian Passports Bill 2004. Bills Digest no. 75-77, Canberra: Parliamentary Library.

Doty, R.L. (1996) 'Sovereignty and the nation: constructing the boundaries of national identity,' In T. Biersteker \& C. Weber (eds.) State Sovereignty as Social Construct, Cambridge: Cambridge University Press, 121-47.

Downer, A. (June 4, 2003) Australia Leads the Way on Passport Biometrics. Media Release FA60, Minister for Foreign Affairs, Accessed 12 December 2004, www.foreignminister.gov.au/releases/2003/fa060_03.html.

Downer, A. (October 25, 2005) Australia Launches ePassports. Media Release FA132, Minister for Foreign Affairs. Accessed 30 May 2007, www.foreignminister.gov.au/releases/2005/fa132_05.html.

Ericson, R. and K. Haggerty. (1997) Policing the Risk Society. Toronto: University of Toronto Press.

Feeley, M. and J. Simon. (1994) ‘Actuarial Justice: The Emerging New Criminal Law,’ In D. Nelken (ed) The Futures of Criminology, London: Sage, 173-201.

Garland, D. (1996) 'The limits of the sovereign state: Strategies of crime control in contemporary society,' British Journal of Criminology, 36(4): 445-71.

Garland, D. (1997) “'Governmentality” and the problem of crime: Foucault, criminology, sociology,' Theoretical Criminology, 1(2): 173-214.

Graham, S. and D. Wood. (2003) 'Digitizing surveillance: categorization, space, inequality,' Critical Social Policy, 23(2): 227-48.

Green, P. and M. Grewcock. (2002) 'The War Against Illegal Immigration: State crime and the construction of a European identity,’ Current Issues in Criminal Justice, 14(1): 87-101.

Howard, J. (2005, September 21). Securing and Policing Australia's Airports. Prime Minister of Australia Media Release, Accessed $\quad$ October 2006 www.pm.gov.au/news/media_releases/media_Release1574.html.

Human Rights and Equal Opportunities Commission (HREOC) (1998) Those Who've Come Across the Seas: Detention of Unauthorized Arrivals, 11 May 1998, Commonwealth of Australia, Canberra.

Huysmans, J. (2000) 'The European Union and the Securitization of Migration,' Journal of Common Market Studies, 38(5): 751-77.

International Campaign Against Mass Surveillance (2005). The Emergence of a Global Infrastructure for Mass Registration and Surveillance, Accessed 12 November 2005, http://www.i-cams.org.

Johnston, L. and C. Shearing. (2003) Governing Security: Explorations in Policing and Justice. London, Routledge.

Joly, D., L. Kelly and C. Nettleton. (1997) Refugees in Europe: The Hostile New Agenda. London, Minority Rights Group.

Loader, I. (2002) ‘Policing, securitization and democratization in Europe,’ Criminal Justice, 2(2): 125-53.

Lyon, D. (2006a) 'The border is everywhere: ID cards, surveillance and the other,' In E. Zuriek \& M.B. Salter (eds.) Global Surveillance and Policing: Borders, Security and Identity, Cullompton: Willan, 66-82. 
Lyon, D. (2006b) 'Airport Screening, Surveillance and Social Sorting: Canadian Responses to 9/11 in Context,' Canadian Journal of Criminology and Criminal Justice, 48(3): 397-411.

Lyon, D. (2004) 'Identity cards: social sorting by database,' Internet Issue Brief No. 3, Oxford: Oxford Internet Institute, University of Oxford.

Lyon, D. (2003) 'Surveillance as social sorting: computer codes and mobile bodies,' In D. Lyon (ed) Surveillance as Social Sorting: Privacy, Risk and Digital Discrimination, London: Routledge, 1330.

McCulloch, J. (2004a) 'National (In) Security Politics in Australia: Fear and the federal election,' Alternative Law Journal, 29(2): 87-91.

McCulloch, J. (2004b) 'Blue Armies, Khaki Police and the Cavalry on the New American Frontier,' Critical Criminology, 12(3): 309-26.

McCulloch, J. and B. Carlton (2006) 'Preempting Justice: Suppression of Financing of Terrorism and the "War on Terror,”' Current Issues in Criminal Justice, 17(3): 397-412.

Muller, B. (2004) '(Dis)Qualified Bodies: Securitization, Citizenship and "Identity Management,"” Citizenship Studies, 8(3): 279-94.

O’Malley, P. (2006) 'Risk, Ethics and Airport Security,' Canadian Journal of Criminology and Criminal Justice, 48(3): 413-21.

Parliament of the Commonwealth of Australia (House of Representatives) (2003) Migration Legislation Amendment (Identification and Authentication) Bill 2003 Explanatory Memorandum, Canberra: Parliament of the Commonwealth of Australia.

Parsley, C. (2003) 'Performing the border: Australia's judgment of “unauthorised arrivals” at the airport,' Australian Feminist Law Journal, 18: 55-75.

Pickering, S. (2001) 'Common Sense and Original Deviancy: News Discourses and Asylum Seekers in Australia,’ Journal of Refugee Studies, 14(2): 169-86.

Pickering, S. (2004) 'The Production of Sovereignty and the Rise of Transversal Policing: Peoplesmuggling and Federal Policing,' Australian and New Zealand Journal of Criminology, 37(3): 36279.

Pickering, S. (2005) Refugees and State Crime. Sydney: Federation Press.

Pickering, S. and L. Weber (2006) 'Borders, mobility and technologies of control,' In Pickering, S. and Weber, L. (eds.) Borders, Mobility and Technologies of Control, Dordrecht: Springer, 1-19.

Privacy International (2004) Mistaken Identity: Exploring the Relationship between National Identity Cards and the Prevention of Terrorism. Interim Report, April. London: Privacy International www.privacyinternational.org.

Rose, N. (2000) ‘Government and Control,’ British Journal of Criminology, 40(2): 321-39.

Ruddock, P. (2001) Background Paper on Unauthorised Arrival Strategy (6 Sept), Ministerial Press Release MPS 131/2001, Accessed 10 January 2006, www.minister.immi.gov.au/media/mediareleases/2001/r01131.htm

Salter, M.B. (2004) 'Passports, Mobility, and Security: How Smart Can the Border Be?' International Studies Perspectives, 5(1): 71-91. 
Salter, M.B. (2006) 'The Global Visa Regime and the Political Technologies of the International Self: Borders, Bodies, Biopolitics,' Alternatives: Global, Local, Political, 31(2): 167-89.

Salter, M.B. (2007) 'Governmentalities of an airport: heterotopia and confession,' International Political Sociology, 1(1): 49-66.

Sassen, S. (1996) Sovereignty in an age of globalization. New York, Columbia University Press.

Shearing, C. and L. Johnston (2005) 'Justice in the Risk Society,' Australian and New Zealand Journal of Criminology, 38(1): 25-38.

Sheptycki, J. (1995) 'Transnational policing and the makings of a postmodern state,' British Journal of Criminology, 35(4): 613-35.

Sheptycki, J. (1998) 'The global cops cometh: reflections on transationalization, knowledge work and policing subculture,' British Journal of Sociology, 49(1): 57-74.

Simon, J. (1997) 'Governing through Crime,’ In L. Friedman \& G. Fisher (eds.) The Crime Conundrum: Essays on Criminal Justice, Boulder, CO: Westview Press, 171-89.

Taylor, S. (2005a) ‘Sovereign Power at the Border,' Public Law Review, 16: 55-77.

Taylor, S. (2005b) 'Offshore Barriers to Asylum Seeker Movement: The exercise of power without responsibility? Moving On: Forced Migration and Human Rights.' Conference paper delivered at University of Sydney Centre for International and Global Law, 22 November 2005. No pagination.

Thomas, R. (2005) 'Biometrics, international migrants and human rights,' Global Migration Perspectives, No. 17. Geneva: Global Commission on International Migration (GCIM). http://www.gcim.org/gmp.

Van der Ploeg, I. (2006) 'Borderline Identities: The Enrollment of Bodies in the Technological Reconstruction of Borders,' In T. Monahan (ed) Surveillance and Society: Technological Politics and Everyday Life, New York: Routledge, 177-93.

Wæver, O. (1995) 'Securitization and Desecuritization,' In R. Lipschutz (ed) On Security. New York: Columbia University Press, 46-86.

Walters, W. (2006) ‘Border/Control,' European Journal of Social Theory, 9(2): 187-203.

Weber, L. (2002) 'The detention of asylum seekers: 20 reasons why criminologists should care,' Current Issues in Criminal Justice, 14(1): 9-30.

Weber, L. (2006) 'The shifting frontiers of migration control,' In S. Pickering and L. Weber. (eds) Borders, Mobility and Technologies of Control. Amsterdam: Springer, 21-44.

Weber, L. (2007) 'Policing the Virtual Border: Punitive Preemption in Australian Offshore Migration Controls', Social Justice: Special Issue on Transnational Criminology 34(2)

Weber, L. and B. Bowling. (2004) 'Policing Migration: A framework for investigating the regulation of global mobility,' Policing and Society, 14(3), 195-212.

Welch, M. and L. Schuster (2005) ,Detention of asylum seekers in the US, UK, France, Germany and Italy: A critical view of the globalizing culture of control,' Criminal Justice, 5(4): 331-55.

Wheeler, J. (2005) An Independent Review of Airport Security and Policing for the Government of Australia. Canberra: Commonwealth of Australia. 
Williams, M. (2003) 'Words, Images, Enemies: Securitization and International Politics,' International Studies Quarterly, 47(4): 511-31.

Wilson, D. (2006) 'Biometrics, Borders and the Ideal Suspect,' In S. Pickering and L. Weber (eds.) Borders, Mobility and Technologies of Contro,. Dordrecht: Springer, 87-109.

Wonders, N. (2006) 'Global flows, semi-permeable borders and new channels of inequality,' In S. Pickering and L. Weber (eds.) Borders, Mobility and Technologies of Control, Dordrecht: Springer, 63-86.

Woolner, D. (2001) 'The Developing Policy Pressures in Australian Coastal Surveillance.' Canberra, Research Paper No. 20, Parliamentary Library, Canberra www.aph.gov.au/library/pubs/rp/200001/01RP20.htm.

Zedner, L. (2007) 'Preventive Justice or Pre-Punishment? The case of control orders,' in C. O'Cinneidl and J. Holder (eds.) Current Legal Problems 60. Oxford: Oxford University Press 